\title{
Optimizing Placement of Field Experience Program: An Integration of MOORA and Rule-Based Decision Making
}

\author{
Okfalisa Okfalisa ${ }^{1 *}$, Rizka Hafsari ${ }^{1}$, Gusman Nawanir ${ }^{2}$, Saktioto Toto ${ }^{3}$ and \\ Novi Yanti ${ }^{1}$ \\ ${ }^{1}$ Informatics Engineering Department, Universitas Islam Negeri Sultan Syarif Kasim Riau, 28293 Pekanbaru, \\ Riau, Indonesia \\ ${ }^{2}$ Faculty of Industrial Management, Universiti Malaysia Pahang, 26300 UMP, Kuantan, Pahang, Malaysia \\ ${ }^{3}$ Physic Department in Universitas Riau, 28293 Pekanbaru, Riau, Indonesia
}

\begin{abstract}
The lack of optimality in the Field Experience Program (FEP) placement has affected universities' educational services to the stakeholders. Bringing together the stakeholders' needs, university capacities, and participants' willingness to quality and quantity is not easy. This study tries to optimize the placement of FEP by considering the interests of multiple perspectives through the application of Multi-Objective Optimization on the Basic of Ratio Analysis (MOORA) and Rule-Based methods in the form of a decision-making model. MOORA ranked the students based on the FEP committee's perspective and other criteria, such as micro-teaching grades, final GPAs, study programs, number of credits, and student addresses. Meanwhile, the school perspective was ordered based on its accreditations, levels, types, facilities, and performances. To achieve the optimal recommendation of FEP placement, the integration of MOORA and Rule-based intertwined the requirement of such perspectives. A prototype of the system recommendation is then acquired to simplify the decision-making model. As adjudications, a survey from twenty stakeholders evidenced around $86.92 \%$ of system user acceptances. The confusion matrix testing defines the

ARTICLE INFO

Article history:

Received: 28 October 2020

Accepted: 03 February 2021

Published: 30 April 2021

DOI: https://doi.org/10.47836/pjst.29.2.11

$\overline{\text { E-mail addresses: }}$ accuracy of this method reaches $78.33 \%$. This paper reveals that the recommendation model has been successfully increasing the effectiveness of decision making in FEP placement under the needs and expectations of the entire stakeholders.
\end{abstract}

okfalisa@gmail.com (Okfalisa Okfalisa)

rizkahafsari@gmail.com (Rizka Hafsari)

gusman@ump.edu.my (Gusman Nawanir)

saktioto@yahoo.com (Saktioto Toto)

novi_yanti@uin-suska.ac.id (Novi Yanti)

* Corresponding author

Keywords: Decision support system, multiple perspectives, optimization, recommendation system, rule-based 


\section{INTRODUCTION}

The FEP is a program to improve students' quality, a mandatory requirement before taking the final assignment course at the Faculty of Education and Teacher Training. In this program, the students carry out teaching practices and other academic activities at junior and senior high school levels set by the FEP committee for two months. Based on interviews with FEP committees, several obstacles were found, including ineffective administrative procedures, which took a long time to access and overload student placements in one school. Besides, some complaints are considered related to the quality and imbalance of student competencies delivered by school needs. The school mileage factor also becomes an obstacle for the students in applying discipline and finance in implementing programs. This equip became a significantly affecting issue, especially for initial teachers in establishing their professional identities (Gang et al., 2020). Feelings of professional unease and discomfort during the first year of teaching regarding the teacher educators' substantial and situational selves kindly influence new pedagogies and the confident practitioner towards achieving new professional identity (Julie \& Katie, 2017). The initial teachers require adequate induction support to analyze the knowledge, interpret and understand the education environment setting, mission statement, curriculum, and precise nature of work; and understand the teaching. These processes help the new teacher educator evolve their epistemic, overview knowledge of schooling, the establishment and extended of pedagogy, and provide a potential platform for evaluating what to teach, when, and how (Jones et al., 2020). The world of education continues to grow and is greatly influenced by the development. Thus, it directly affects the educational system. Teachers are responsible for operating the educational system and ensuring the sustainable achievement of schools' objectives and curriculum. To date, a strong and efficient professional competency of teachers should be redefined on the development of human life and education as field competencies, pedagogical competencies, research competencies, curriculum competencies, lifelong learning competencies, social-cultural competencies, emotional competencies, communication competencies, information and communication technologies competencies and environmental competencies (Selvi, 2010). The above competencies imply developing students' competencies towards acquiring self-confidence, learning motivation, and social skills (Chan \& Yeung, 2019). This issue aims to allow academics in the field to study and assess their lessons and skills critically. Yeo et al. (2008) found that teachers' efficacy in instruction, classroom management, and student engagement influenced the teacher attributes and the teacher-student relationship. Zendarski et al. (2020) examined the teacher characteristics, thus relating to the social culture competencies that significantly contributed to the child-teacher relationship quality.

In a nutshell, this research tries to respond to the importance of the teacher's roles on the student education in schools, mostly related to the formation of professionalism of the new 
teachers; a high demand of policy and effective mechanism during the placement of students as prospective teachers in this FEP; and the consideration of stakeholders' perspectives at the side of students' needs, FEP committees, and schools. These three perspectives give a new contribution to a more objective assessment and decision-making by developing a Decision Support System (DSS) towards FEP placement effectiveness. Thus, it provides opportunities for the professional development of new practical teachers. DSS is an application that aids in providing management recommendations in making decisions more objective by considering various alternatives and criteria defined. Understanding the knowledge-based components in decision-making (performance, attitude, and behavior) will enhance managers' influential role and key actors in making decisions (Bonjar et al., 2019). The application of DSS in assisting management decision making, especially in education, has been widely carried out (Delen et al., 2020). The EVALOE- DSS framework for teacher professional development has been recently designed by Gràcia et al. (2020) with the intention of increasing diverse student linguistic skills. Pardiyono and Indrayani (2019) applied the DSS concept in choosing private higher education based on the marketing mix model criteria. Ardana et al. (2016) developed a DSS model to select blended learning platforms for Mathematic and Information Communication Technology (ICT) learning.

Meanwhile, Ibrahim et al. (2014) integrated the DSS framework for strategic planning in Higher Education Institutions. The above research flourished the significant and successful DSS roles in solving the management, technical, professional, social and culture problems related to decision-making in education fields. Herein, the performance of the FEP program through the practice of DSS approach is strongly optimistic.

Unfortunately, most of the raised studies deploy a single perspective in solving the complexity of DSS problems. In reality, a synthesis of broad worldviews is essentially developed rather than a single perspective to recognize complex social problems' connectedness. The development of multiple perspectives generates open, honest, effective dialogues and trust among the relevant stakeholders affected by the decision. Hsu et al. (2020) explored the multiple perspectives of experts' evaluation in generating a set of influence criteria in promoting the healthcare industry innovative technologies. Meanwhile, Petkov et al. (2007) studied how the multiple perspective representations of complex managerial problems could support the integration of Multi-Attribute Decision Making (MADM) and soft systems methodologies. El-Gayar and Fritz (2010) presented a web-based multi-perspective DSS for information security planning. Yazdani et al. (2017) had successfully developed a group decision making approach in assisting the multiple perspectives of decision makers and customers values in selecting third-party logistic providers. The result revealed that the multiple perspectives substantially rose in the efficient decision support system towards the quality and reliability of decisions. The multiple perspective approach above has successfully bridged qualitative value judgments 
with the quantitative data relative criteria to address inquiring organizations' needs. The analysis provided captures the relevant stakeholders' subjective preferences for dealing with conflict priority and presents the trade-offs in a decision fairly.

Moreover, group decision making let the participants boost their ability to learn and stimulate their cognitive level (Carneiro et al., 2020). Therefore, the adoption of three multiple perspectives in this research (i.e., of students, FEP committees, and schools) enhances decision-making effectiveness. More importantly, organizational learning continues towards sustainable gains in productivity and organizational excellence. Many methods have been applied in figuring out the problems related to MADM, including the simple additive weighting method (SAW) (Engel et al., 2017), the analytic hierarchy process (AHP) (Fox et al, 2015; Okfalisa et al., 2018; Leny \& Okfalisa, 2019), and the technique for order preference by similarity to ideal solution (TOPSIS) (Conejero et al., 2020), ELECTRE (Mishra et al., 2020) and the latest is MOORA (Okfalisa et al., 2020). Besides, Martusorn et al. (2019) tried to compare the effectiveness of SAW, AHP, and TOPSIS in selecting a suitable warehouse location. The existing techniques have exclusively addressed their benefits and highlighted the attributes of various analyses such that their value can be clarified by using the technique-based of case completion efficiently. As comparatively, the AHP approach and its derivatives, including ANP, Fuzzy AHP, and Fuzzy ANP have intensity emphasizes resolving the bias of weight assessment and analysis sensitivity (Okfalisa et al., 2021). The reviews of MADM methods are disclosed at Table 1.

MOORA was first introduced by Brauers and Zavadskas (2006) to work out the various complex and conflicting decision-making issues for optimal decision purposes. MOORA responds to the representative alternatives concerning that particular objective by calculating the square root of each alternative's sum of squares per objective chosen (Brauers, 2008). MOORA accommodates multiple criteria in simple computational procedures. Thus, a particular single equation is required for decision matrix normalization irrespective of the nature criteria (Madić et al., 2015). This technique has been successfully showing the perfect correlation for order preference to the ideal solution. It is not affected by introducing any additional parameters (Stanujkic et al., 2012) and undefined of the criteria weights (Chakraborty, 2011). MOORA can simultaneously consider the numbers of quantitative and qualitative selection attributes (Gadakh et al., 2013).

The MOORA application in various scientific fields has been carried out, including MOORA and Goal Programming for solving credit lending decision-making problems for real-time commercial banking environment (Yusuf, 2019), AHP-MOORA for solving the composite material selection for structural component development. Herein, the ration system, multiplicative, and the reference point of MOORA used to compare and rank the proposed materials (Patnaik et al., 2020), integrated MOORA and DEMATELANP to provide optimum sensitivity analysis and consistency decision-makers' priorities 
Table 1

The reviews of MADM approaches

\begin{tabular}{|c|c|c|c|}
\hline $\begin{array}{l}\text { MADM } \\
\text { Approach }\end{array}$ & Advantages & Method Extension & Reference \\
\hline AHP & $\begin{array}{l}\text { 1. Focus on weighting of evaluation } \\
\text { criterion. } \\
\text { 2. Determine the significant weight } \\
\text { and prioritize of criterion } \\
\text { 3. Dealing with human bias during } \\
\text { the knowledge transformation of } \\
\text { decision makers }\end{array}$ & $\begin{array}{l}\text { AHP-Entropy; } \\
\text { AHP-OMAX; Fuzzy } \\
\text { AHP; Fuzzy C Mean } \\
\text { (FCM) - Fuzzy AHP; } \\
\text { Quality Function } \\
\text { Deployment (QFD) } \\
\text { - Fuzzy ANP; Fuzzy } \\
\text { AHP; ANP }\end{array}$ & $\begin{array}{l}\text { Du et al. (2020); } \\
\text { Okfalisa et al. (2018); } \\
\text { Mangla et al. (2017); } \\
\text { Kazemi et al. (2020); } \\
\text { Mistarihi et al. (2020); } \\
\text { Li et al. (2020) }\end{array}$ \\
\hline SAW & $\begin{array}{l}\text { 1. Commonly applied for converted } \\
\text { negative criteria into positive value. } \\
\text { 2. Determine the weighted summation } \\
\text { values for each alternative and } \\
\text { assessment criteria. } \\
\text { 3. Finding the complete ranking of the } \\
\text { alternatives }\end{array}$ & $\begin{array}{l}\text { SAW-HFL Additive } \\
\text { Ratio Assessment } \\
\text { (ARAS); AHP - SAW; } \\
\text { Fuzzy SAW and Fuzzy } \\
\text { TOPSIS; Fuzzy SAW }\end{array}$ & $\begin{array}{l}\text { Büyüközkan \& Güler } \\
\text { (2020); Kumar et al. } \\
\text { (2019); } \\
\text { Roszkowska \& } \\
\text { Kacprzak (2016); } \\
\text { Mukodimah et al. } \\
\text { (2018); Engel et al. } \\
\text { (2017) }\end{array}$ \\
\hline TOPSIS & $\begin{array}{l}\text { 1. Can be used to determine the } \\
\text { weights of decision makers } \\
\text { 2. Commonly applied for ranking the } \\
\text { alternatives and to select the best } \\
\text { one } \\
\text { 3. Considering both positive-ideal and } \\
\text { negative-ideal solutions in decision- } \\
\text { making. }\end{array}$ & $\begin{array}{l}\text { Fuzzy TOPSIS; } \\
\text { TOPSIS; TOPSIS with } \\
\text { Hesitant Pythagorean } \\
\text { Fuzzy Sets. }\end{array}$ & $\begin{array}{l}\text { Gündoğdu \& Kahraman } \\
\text { (2019); Kacprzak } \\
\text { (2019); Liang \& Xu } \\
\text { (2017); Memari et al. } \\
\text { (2019); De Farias Aires } \\
\text { \& Ferreira (2019); } \\
\text { Martusorn et al. (2019); } \\
\text { Conejero et al. (2020). }\end{array}$ \\
\hline ELECTRE & $\begin{array}{l}\text { 1. Can be used to calculate and rank } \\
\text { the criteria and alternatives. } \\
\text { 2. Famous for its outranking relations } \\
\text { to rank a set of alternatives. } \\
\text { 3. Applied to determine the concepts } \\
\text { of concordance and discordance } \\
\text { relations among alternatives. } \\
\text { 4. Effective application in group } \\
\text { decision-making environment }\end{array}$ & $\begin{array}{l}\text { Intuitionistic Fuzzy } \\
\text { (IF)-DEMATEL } \\
\text { and IF-ELECTRE; } \\
\text { ELECTRE III with } \\
\text { weighted Borda rule; } \\
\text { ELECTRE; ELECTRE } \\
\text { and Pythagorean Fuzzy } \\
\text { Sets }\end{array}$ & $\begin{array}{l}\text { Kilic et al. (2020); Liao } \\
\text { et al. (2020); Fei et al. } \\
\text { (2019); Mishra et al. } \\
(2020) \text {; } \\
\text { Akram et al. (2019). }\end{array}$ \\
\hline MOORA & $\begin{array}{l}\text { 1. Overing some of the available } \\
\text { decision-making methods include } \\
\text { fewer mathematical computations, } \\
\text { less computational time, more } \\
\text { simplicity, and more stability } \\
\text { compared with other MADM } \\
\text { 2. Proposing optimum materials and } \\
\text { stable ranking result. } \\
\text { 3. One of the latest MADM methods } \\
\text { that covers the weakness of other } \\
\text { older methods. } \\
\text { 4. Has been applied in many selections } \\
\text { case study and fields of research } \\
\text { background. }\end{array}$ & $\begin{array}{l}\text { FCM - MOORA; } \\
\text { Fuzzy MOORA; } \\
\text { Fuzzy MOORA - } \\
\text { FMEA; MOORA; } \\
\text { MULTIMOORA; } \\
\text { AHP-MOORA; } \\
\text { MOORA and Goal } \\
\text { Programming; } \\
\text { MOORA and } \\
\text { DEMATEL-ANP; } \\
\text { MOORA-based } \\
\text { Taguchi }\end{array}$ & $\begin{array}{l}\text { Dabbagh \& Yousefi } \\
\text { (2019); Emovon } \\
\text { et al. (in Press); } \\
\text { Arabsheybani et al. } \\
\text { (2018); Shihab et al. } \\
\text { (2018); Omrani et al. } \\
\text { (2019); Yusuf (2019); } \\
\text { Patnaik et al. (2020); } \\
\text { Dinçer et al. (2019); } \\
\text { Liang et al. (2020). }\end{array}$ \\
\hline
\end{tabular}


for the recommendation of the financial service in E7 economy evolution (Dinçer et al., 2019), application of MOORA-based Taguchi method for predicting the optimal welding parameters by considering the multiple quality of perspectives (Liang et al., 2020), MOORA and FCM as a hybrid decision-making system for prioritizing Occupational Health and Safety (OHS) risks based on the proposed weight of FCM approach (Dabbagh \& Yousefi, 2019). As a result, the previous works derived that MOORA can consider all the attributes essential and provided a better accurate evaluation of the alternatives. Arabsheybani et al. (2018) also found that MOORA accommodated the optimum decision-making methods with uncomplicated mathematical computations, low execution time, more simplicity, and revealed stable ranking result compared with others MADM techniques.

Moreover, the sensitivity analysis approach of MOORA continues to evolve and be enhanced through the integration process with various MADM approaches.

Therefore, this study applies the MOORA method in prompting the proposed alternatives by each perspective. Every perspective has measurable attributes to quantitatively well-defined the alternative solutions, viz., micro-teaching grades, final GPA, study programs, number of credits and student address, the school accreditation, the school level, the school type, the school facilities, and the school performance. The objective consists of the optimization model as well as maximization or minimization of an attribute. The satisfaction of all perspectives becomes the primary consideration that must be revealed in this research. Herein, MOORA defines the robustness in connection with multiple objectives and conditions set in this case.

Furthermore, to inextricably link the MOORA optimization ranking from both perspectives, a rule-based concept with forwarding chaining inference is applied. Rulebased is capable of selecting the minimal and representative criteria objectively and reliably for forming the MADM model and overlooking the inter-relationships among the involved criteria towards the continuous improvement and the measurement of underestimated effect of non-additive aggregators (You et al., 2019). By deploying the rule bases, the MADM method can translate decision-makers' knowledge and explanation facilities into quantitative and qualitative analytical functions. The integration of body knowledge in MADM and the expert system paradigm is represented by a MOORA and Rule-based embodiment, thus explicitly articulating the stakeholders' knowledge about a particular decision-making issue. Thus, the recommendations given are expected to meet each perspective's needs and interests by considering the defined criteria' value.

The suitable pair proposed is, without a doubt, the most incredible combination according to the parameters' significance. As a limitation, this research was conducted on the execution of the FEP at Education and Teacher Training Faculty of Universitas Islam Negeri Sultan Syarif Kasim Riau, which involved a total number of 1,036 students in the year 2018/2019 from seven study programs, including the Islamic Religious Education, 
Arabic Language Education, English Language Education, Economic Education, Chemical Education, Mathematics Education, and Counseling Guidance.

\section{MATERIALS AND METHODS}

Several activities were carried out this research. First, the problem identification process was put into practice qualitatively through interviews and focus group discussion with one FEP manager, two heads of departments, two deputy dean, two schools' management, and thirty-five students as participants. The FEP managers, head departments, deputy dean, and schools' management were asked due to their responsibility in handling this program. Meanwhile, the representative students from the post participants were discussed their problematics and expectation of this program. As a result, a pattern of the FEP procedure was defined. The emerging of various obstacles encountered during the execution from both perspectives. Several possible variables were also formulated and proposed as criteria, such as the students perceives criteria viz., the value of micro-teaching (C1), final GPA (C2), program study (C3), credit numbers (C4), and student address (C5). Concurrently, the school apprehends criteria expressly school accreditation (C1), school level (C2), school type (C3), school facilities-Wifi (C4), school facilities-labour (C5), school facilities-library (C6), school facilities-air conditioner (C7), and school performance-Adiwiyata (C8). The determination of criteria weight for the FEP placement was set during the discussion (details are described in the Result and Discussion section). Quantitative literature reviews have been structured to reinforce the formulation of standards. As the main activity, the optimization analysis of current program participants delegated by forty students and ten schools was preliminarily examined through MOORA.

A series of MOORA flow processes is followed, namely the formation of matrices (Equation 1), the determination of normalized matrices (Equation 2), the determination of weighted normalization matrices (Equation 3), and the determining preference values (Equation 4).

1. Matrix Formation

$$
X i j=\left[\begin{array}{lll}
X 11 & X 12 & X 1 n \\
X 21 & X 22 & X 2 n \\
X m 1 & X m 2 & X m n
\end{array}\right]
$$

$x i j=$ the result of matrix formation

$x=$ the value of each criterion

$i=$ the criterion value

$j \quad=$ the alternative value

$m=$ the criterion value to $m$

$n=$ the alternative value to $n$ 
2. Normalize matrix determination

$$
x \overline{i j}=\frac{x i j}{\sqrt{\sum_{j=1}^{m} x^{2} i j}}
$$

$(j=1,2 \ldots, n)$

$x \overline{i j}=$ the average of the $i_{-}{ }^{\text {th }}$ criteria to the value of the $j_{-}{ }^{\text {th }}$ criteria

$x i j=$ the matrix formation

$i=$ the value derived from the number of criteria

$j \quad=$ the value derived from the number of alternatives

$n=$ the number of alternative values up to $n$

3. Weighted normalize matrix determination

$$
y i=\sum_{j=1}^{g} X i j * \sum_{j=g+1}^{n} W j
$$

$y i=$ the result of weighted matrix multiplication

$w j=$ the weight value of the $\mathrm{j}^{\text {th }}$ criterion

$x i j=$ values of each matrix formation

4. Preference value determination

$$
y i=\sum_{j=1}^{g} W j X i j-\sum_{j=g+1}^{n} W j X i j
$$

$y i=$ the result of weighted matrix multiplication

$w j=$ the weight value of the $\mathrm{j}^{-{ }^{\text {th }}}$ criterion

$x i j=$ values of each matrix formation

Finally, the highest rank of student and school alternatives was merged using the rule-based to track the appropriate recommendation pair. A decision tree diagram is then developed based on the association rules defined by the stakeholders. To automate the integration of MOORA and rule-based calculation, a prototype DSS was constructed. Object-Oriented and Unified Modeling Language (UML) tools were applied in system analysis and design. These tools have demonstrated a promising future as a pragmatic methodology in modelling DSS, including user interface, architectural design, analysis and design, programming, data management, and model management (Liu \& Stewart, 2004). The visualization derives from this powerful approach is capable in interactively express the immersive learning of information and knowledge of the respondent, as examples Kumar et al. (2019) designed web-based object-oriented decision support system for coastal 
water quality prediction and Sztubcka et al. (2020) deployed Geographic Information Systems as innovative DSS in identifying the potential location for energy efficiency improvement. Thus, the adoption of the object-oriented technique has been successfully generated the dynamic analytical and development of multi-attribute decision making components of DSS. Furthermore, Blackbox Testing, User Acceptance Testing (UAT), and Confusion Matrix were systematically organized in testing the work out functionality, the user responses, and the accuracy comparison for 120 test data simulation. Blackbox testing and UAT are commonly and effectively applied for software development testing (Pressman \& Maxim, 2020).

Below is the description of the Confusion Matrix. It is acceptable and straightforward for classification algorithms and area estimation models (Lewis \& Brown, 2001; Han at al., 2011) (Equation 5 \& 6).

$$
\begin{aligned}
& \text { Accuracy }=\frac{T P+T N}{P+N} \times 100 \% \\
& \text { Error-rate }=\frac{F P+F N}{P+N} \times 100 \%
\end{aligned}
$$

TP $($ True Positive) $=$ The amount of correctly classified data (Actual class (yes), Predicted class (yes)).

TN (True Negative) $=$ The amount of correctly classified data (Actual class (no), Predicted class (no)).

FN (False Negatif) = The amount of incorrectly classified data (Actual class (yes), Predicted class (no)).

FP (False Positif) = The amount of incorrectly classified data (Actual class (no), Predicted class (yes)).

$P=$ Total of $T P$ and $F N$

$N=$ Total of $F P$ and $T N$

Blackbox Testing is a structural software evaluation technique used to analyze system functionality, requirement analysis validation, system integration relates to the codification review, acknowledging the customer's requirement analysis phase, and the system regression test (Nidhra, 2012; Copeland, 2004). Meanwhile, UAT is conducted by disseminating the questionnaire with five Linkert scales to measure the respondents' agreement related to the system utilization, procedures, and the recommendations offered by this prototype DSS system (Davis \& Venkatesh, 2004). UAT is essential in grabbing information and profound knowledge relevant to the validation and acceptance of the solution. 


\section{RESULTS AND DISCUSSIONS}

\section{Problem Identification}

Based on the observations and interviews, the flow of FEP student placement activities is described in Figure 1. The current system was manually performed and randomly positioned without considering any particular criteria. Students enrolled for the FEP program at the front desk of committee services. Next, the committee checked the validity of documents' requirements by referencing the faculty data, including students' status, micro-teaching score, final GPA, study programs, and credits. The committee applied word and excel programming to make the recapitulation and data classification. Finally, the committee randomly placed the students for the FEP program. The FEP placement report will be announced and conducted based on the proposed date and schools. As a result, manually operated of registration, data validation, and data recapitulation triggered the un-effective time management on the side of committee services. Lack of students' discipline during the registration process caused the target's achievement not to set as expected. The committee services were disappointed on the schools' side, especially regarding time management, students' quality and competencies, students' discipline, students' requirements, and quota allocation. By referring to Indonesia's government regulation No. 13 the Year 2015 about national education standard, Indonesia Ministry of Environment No. 05 the Year 2013, and focus group discussion summary during the interview session, student performance can be assessed through the score value of micro-teaching, final GPA, program study, numbers of credits, and students' location. Microteaching provides a space for the pre-service teacher to evaluate their teaching (Saban \& Coklar, 2013) by considering the timing, planning, asking questions, management of the class, materials usage, and physical appearance in front of the class. The value of micro-teaching practices contributes to the pre-service teachers' qualifications and experiences. Hemdi et al. (2016) found that the cumulative GPA recognized as the holistic student academic assessment mechanism clearly described their actual ability, knowledge, skills, and attitude. Understanding GPA is beneficial for the students, faculty, university, and external stakeholders in identifying the students' strengths

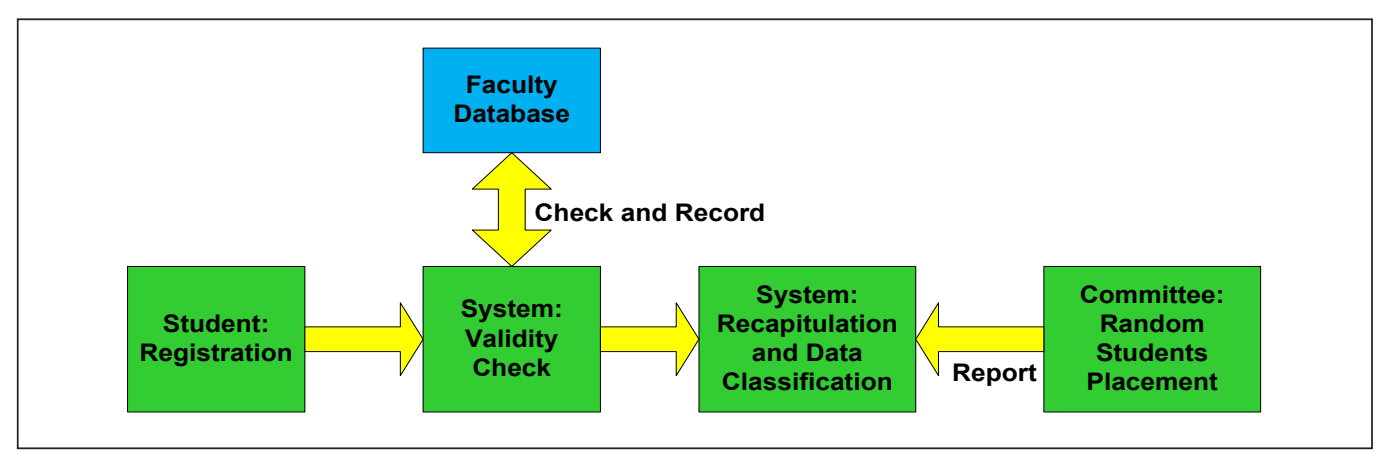

Figure 1. Flow diagram for FEP student placement 
and weaknesses for vacancy allocation. Concurrently, the school appraisal encompasses the school accreditation, the school level, the school type, the school facilities, and the school performance. School accreditation evaluates the school's quantitative educational quality judgment of facilities, resources, and teaching. The accreditation mirrors the broad aspects of teacher competencies and values during the educational program (Davis \& Ringsted, 2006). Cherchye et al. (2010) exhibited that environmental characteristics in terms of the school type private and public sector positively impact the educational output in efficiency and equity. The Indonesian government introduced the Adiwijaya program to encourage knowledge creation and school awareness of nature (Krisnawati et al., 2015). The program embodies the environmental policy, environmental-based curriculum, participative activities, and environmental facilities management. In a nutshell, the school performance is valuably measured through Adiwijaya program availability.

\section{Criteria Formulation}

The formulation of criteria is defined in Tables 2 and 3 . The weights of its priority are put in place following the summing up of focus group discussion. The discussion revealed the weighted of students' criteria as in Table 2, thus C1-The Value of Micro-teaching set as the most priority criteria at 30\% weighted value following by C2-Final GPA, C3-Program Study, C4- Credit Numbers, and C5- Student Address, respectively. The values of Max and Min for each criterion is referred by MOORA regulation for optimum and minimum values. The value of micro-teaching subsumes in grade $\mathrm{A}, \mathrm{A}-, \mathrm{B}+, \mathrm{B}, \mathrm{B}-, \mathrm{C}+$, and $\mathrm{C}$ with weight precedence into score 4.00, 3.70, 3.30, 3.00, 2.70, 2.30, and 2.00, respectively. The final GPA is specified as more than equal to 2.75. Program study is covered into seven programs, viz., Chemistry Education (P1), Economic Education (P2), English Language Education (P3), Mathematics Education (P4), Counseling Education (P5), Islamic Religious Education (P6), and Arabic Language Education (P7) with the weight emphasis from seven to one accordingly. Credit numbers are designated not less than 120 credits. Criteria for student address encompasses the distance from school 0 to 500 meter, 500 to 2000 meter, and more than 2000 meter. The weights are generated into the value of three, two, and one, respectively.

Table 3 explained the weight of school criteria whereby C1-School Accreditation is denoted as the weightiest priority criteria at 30\%. It is then pursued by C2-School Level, C3-School Type, C4-School Facilities (Wifi), C5-School Facilities (labour), C6-School Facilities (Library), C7-School Facilities (Air Conditioner), and C8-School Performance (Adiwiyata), respectively. The school's accreditation (C1) is measured in grades A and B thus, the weights in each case are specified in subject values of four and three. The schoollevel (C2) criteria contain the sub level in senior high school (TS1), Islamic senior high school (TS2), vocational high school (TS3), junior high school (TS4), an Islamic junior 
Table 2

Weight of student criteria

\begin{tabular}{llcl}
\hline No. & Criteria & Weight & Value \\
\hline C1 & The Value of Micro-teaching & $30 \%$ & Max \\
C2 & Final GPA & $25 \%$ & Max \\
C3 & Program Study & $20 \%$ & Max \\
C4 & Credit Numbers & $15 \%$ & Max \\
C5 & Student Address & $10 \%$ & Min \\
\hline
\end{tabular}

Table 3

Weight of school criteria

\begin{tabular}{llcl}
\hline No. & Criteria & Weight & Value \\
\hline C1 & School Accreditation & $30 \%$ & Max \\
C2 & School Level & $25 \%$ & Max \\
C3 & School Type & $15 \%$ & Max \\
C4 & School Facilities (Wifi) & $5 \%$ & Max \\
C5 & School Facilities (labor) & $5 \%$ & Max \\
C6 & School Facilities (Library) & $5 \%$ & Max \\
C7 & School Facilities (Air Conditioner) & $5 \%$ & Min \\
C8 & School Performance (Adiwiyata) & $10 \%$ & Min \\
\hline
\end{tabular}

high school (TS5) with the circumscribed weight from five to one, respectively. The school type (C3) is explained in public and private schools by considering the weighted priority in two public and private schools. Concurrently, the school facilities (C4-C7) and performance (C8) are determined by their availability, one weighted for provided, and zero for the rest.

\section{MOORA Analysis}

Following Equation 1, Tables 4 for forty (A1 to A40) students' matrix formation against the values of each criterion ( $\mathrm{C} 1$ to $\mathrm{C} 5$ ) are elucidated. Subsequently, Equation 2 calculation for students' normalization matrix is spelt out as in Table 5. Table 6 is then declared according to the MOORA estimation in Equation 3 to denote the students' weighted matrix's normalization across criteria. Besides, Table 7 indicates the value of student's preference conforming to the Equation 4. Thus, it ranks the students from the highest score of $Y i$ at student-A6 (0.1468), student-A25 (0.1466), student-A27(0.1462), student-A28 (0.1461), student-A20 (0.1455), and student-A22 (0.1452). Furthermore, a similar calculation from Equation 1 to 4 is applied to the side of the school perspective. As a final result, Table 8 shows the schools' place appertaining to the values of $Y i$ where school-A4 as the highest score at 0.2713 , following by school-A3 (0.2610), school-A2 (0.2474), school-A1 (0.2372), school-A8 (0.2067), school-A6 (0.1998), school-A10 (0.1986), school-A5 (0.1833), school-A7 (0.1759), and school-A9 (0.1728) accordingly. 
Table 4

Student matrix formation

\begin{tabular}{cccccc}
\hline $\mathrm{A}$ & $\mathrm{C}_{1}$ & $\mathrm{C}_{2}$ & $\mathrm{C}_{3}$ & $\mathrm{C}_{4}$ & $\mathrm{C}_{5}$ \\
\hline $\mathrm{A}_{1}$ & 3.3 & 3.50 & 5 & 136 & 3 \\
$\mathrm{~A}_{2}$ & 3.3 & 3.17 & 5 & 132 & 1 \\
$\mathrm{~A}_{3}$ & 2.7 & 3.36 & 5 & 136 & 2 \\
$\mathrm{~A}_{4}$ & 3.3 & 3.37 & 5 & 136 & 3 \\
$\mathrm{~A}_{5}$ & 4 & 3.30 & 5 & 136 & 2 \\
$\ldots$. & $\ldots$. & $\ldots$. & $\ldots$. & $\ldots$. & $\ldots$. \\
$\mathrm{A}_{36}$ & 3 & 3.18 & 3 & 132 & 1 \\
$\mathrm{~A}_{37}$ & 3.3 & 3.55 & 3 & 132 & 3 \\
$\mathrm{~A}_{38}$ & 2.7 & 3.73 & 3 & 134 & 1 \\
$\mathrm{~A}_{39}$ & 4 & 3.49 & 3 & 132 & 2 \\
$\mathrm{~A}_{39}$ & 4 & 3.49 & 3 & 132 & 2 \\
$\mathrm{~A}_{40}$ & 2 & 3.26 & 3 & 134 & 3 \\
\hline$\sum \mathrm{C}_{\mathrm{n}}$ & 20.2776 & 21.4116 & 28.5482 & 833.9017 & 13.8203 \\
\hline
\end{tabular}

Table 5

Student normalization matrix

\begin{tabular}{cccccc}
\hline $\mathrm{A}$ & $\mathrm{C}_{1}$ & $\mathrm{C}_{2}$ & $\mathrm{C}_{3}$ & $\mathrm{C}_{4}$ & $\mathrm{C}_{5}$ \\
\hline $\mathrm{A}_{1}$ & 0.1627 & 0.1635 & 0.1751 & 0.1631 & 0.2171 \\
$\mathrm{~A}_{2}$ & 0.1627 & 0.1481 & 0.1751 & 0.1583 & 0.0724 \\
$\mathrm{~A}_{3}$ & 0.1332 & 0.1569 & 0.1751 & 0.1631 & 0.1447 \\
$\mathrm{~A}_{4}$ & 0.1627 & 0.1574 & 0.1751 & 0.1631 & 0.2171 \\
$\mathrm{~A}_{5}$ & 0.1973 & 0.1541 & 0.1751 & 0.1631 & 0.1447 \\
$\ldots$. & $\ldots$. & $\ldots$. & $\ldots$. & $\ldots$. & $\ldots$. \\
$\mathrm{A}_{36}$ & 0.1479 & 0.1485 & 0.1051 & 0.1583 & 0.0724 \\
$\mathrm{~A}_{37}$ & 0.1627 & 0.1658 & 0.1051 & 0.1583 & 0.2171 \\
$\mathrm{~A}_{38}$ & 0.1332 & 0.1742 & 0.1051 & 0.1607 & 0.0724 \\
$\mathrm{~A}_{39}$ & 0.1973 & 0.1630 & 0.1051 & 0.1583 & 0.1447 \\
$\mathrm{~A}_{40}$ & 0.0986 & 0.1523 & 0.1051 & 0.1607 & 0.2171 \\
\hline
\end{tabular}

Table 6

Students normalization weighted matrix

\begin{tabular}{cccccc}
\hline $\mathrm{A}$ & $\mathrm{C}_{1}$ & $\mathrm{C}_{2}$ & $\mathrm{C}_{3}$ & $\mathrm{C}_{4}$ & $\mathrm{C}_{5}$ \\
\hline $\mathrm{A}_{1}$ & 0.0488 & 0.0409 & 0.0350 & 0.0245 & 0.0217 \\
$\mathrm{~A}_{2}$ & 0.0488 & 0.0370 & 0.0350 & 0.0237 & 0.0072 \\
$\mathrm{~A}_{3}$ & 0.0399 & 0.0392 & 0.0350 & 0.0245 & 0.0145 \\
$\mathrm{~A}_{4}$ & 0.0488 & 0.0393 & 0.0350 & 0.0245 & 0.0217 \\
$\mathrm{~A}_{5}$ & 0.0592 & 0.0385 & 0.0350 & 0.0245 & 0.0145 \\
$\ldots$. & $\ldots$. & $\ldots$. & $\ldots$ & $\ldots$. & $\ldots$. \\
$\mathrm{A}_{36}$ & 0.0592 & 0.0333 & 0.0280 & 0.0212 & 0.0145 \\
$\mathrm{~A}_{37}$ & 0.0444 & 0.0371 & 0.0210 & 0.0237 & 0.0072 \\
$\mathrm{~A}_{38}$ & 0.0488 & 0.0414 & 0.0210 & 0.0237 & 0.0217 \\
$\mathrm{~A}_{39}$ & 0.0399 & 0.0436 & 0.0210 & 0.0241 & 0.0072 \\
$\mathrm{~A}_{40}$ & 0.0592 & 0.0407 & 0.0210 & 0.0237 & 0.0145 \\
\hline
\end{tabular}


Table 7

Student preference value

\begin{tabular}{cccc}
\hline $\mathrm{A}$ & $\operatorname{Max}\left(\mathrm{C}_{1}+\mathrm{C}_{2}+\mathrm{C}_{3}+\mathrm{C}_{4}\right)$ & $\operatorname{Min}\left(\mathrm{C}_{5}\right)$ & $\mathrm{Yi}=\operatorname{Max}-\operatorname{Min}$ \\
\hline $\mathrm{A}_{1}$ & 0.1492 & 0.0217 & 0.1275 \\
$\mathrm{~A}_{2}$ & 0.1446 & 0.0072 & 0.1374 \\
$\mathrm{~A}_{3}$ & 0.1387 & 0.0145 & 0.1242 \\
$\mathrm{~A}_{4}$ & 0.1477 & 0.0217 & 0.1260 \\
$\mathrm{~A}_{5}$ & 0.1572 & 0.0145 & 0.1427 \\
$\mathrm{~A}_{6}$ & 0.1540 & 0.0072 & 0.1468 \\
$\ldots$. & $\ldots$. & $\ldots$ & $\ldots$. \\
$\mathrm{A}_{36}$ & 0.1263 & 0.0072 & 0.1190 \\
$\mathrm{~A}_{37}$ & 0.1350 & 0.0217 & 0.1133 \\
$\mathrm{~A}_{38}$ & 0.1286 & 0.0072 & 0.1214 \\
$\mathrm{~A}_{39}$ & 0.1447 & 0.0145 & 0.1302 \\
$\mathrm{~A}_{40}$ & 0.1128 & 0.0217 & 0.0911 \\
\hline
\end{tabular}

Table 8

School preference value

\begin{tabular}{cccccccc}
\hline $\mathrm{A}$ & $\mathrm{Yi}$ & $\mathrm{C}_{1}$ & $\mathrm{C}_{2}$ & $\mathrm{C}_{3}$ & $\mathrm{C}_{4}$ & $\ldots$. & $\mathrm{C}_{8}$ \\
\hline $\mathrm{A}_{4}$ & 0.2713 & 4 & 5 & 2 & 1 & $\ldots$. & 1 \\
$\mathrm{~A}_{3}$ & 0.2610 & 4 & 5 & 1 & 0 & $\ldots$. & 0 \\
$\mathrm{~A}_{2}$ & 0.2474 & 4 & 4 & 2 & 1 & $\ldots$. & 1 \\
$\mathrm{~A}_{1}$ & 0.2372 & 4 & 4 & 1 & 0 & $\ldots$. & 0 \\
$\mathrm{~A}_{8}$ & 0.2067 & 3 & 3 & 1 & 0 & $\ldots$. & 0 \\
$\mathrm{~A}_{6}$ & 0.1998 & 4 & 2 & 2 & 1 & $\ldots$. & 1 \\
$\mathrm{~A}_{10}$ & 0.1986 & 4 & 3 & 2 & 0 & $\ldots$. & 1 \\
$\mathrm{~A}_{5}$ & 0.1833 & 4 & 1 & 1 & 0 & $\ldots$. & 0 \\
$\mathrm{~A}_{7}$ & 0.1759 & 4 & 1 & 2 & 1 & $\ldots$. & 1 \\
$\mathrm{~A}_{9}$ & 0.1728 & 4 & 2 & 1 & 0 & $\ldots$. & 0 \\
\hline
\end{tabular}

\section{Rule-based Application}

Rule-based construction was carried out by considering the variables of the study program (C3) from the students' perspective and school level (C2) from the school's perspective. Decision Tree Diagram can be depicted in Figure 2.

Rule-based development is presented as follows:

Rule 1: IF [P1] OR [P2] THEN [TS1, TS2]

Rule 2: IF [P6] OR [P7] THEN [TS2, TS5]

Rule 3: IF [P3] OR [P4] OR [P5] then [TS1, TS2, TS3, TS4, TS5].

In a nutshell, the selected students at the side of committee perspectives are merged with the preferred schools from the school perspective. Thus, it is pursuing the rule-based 


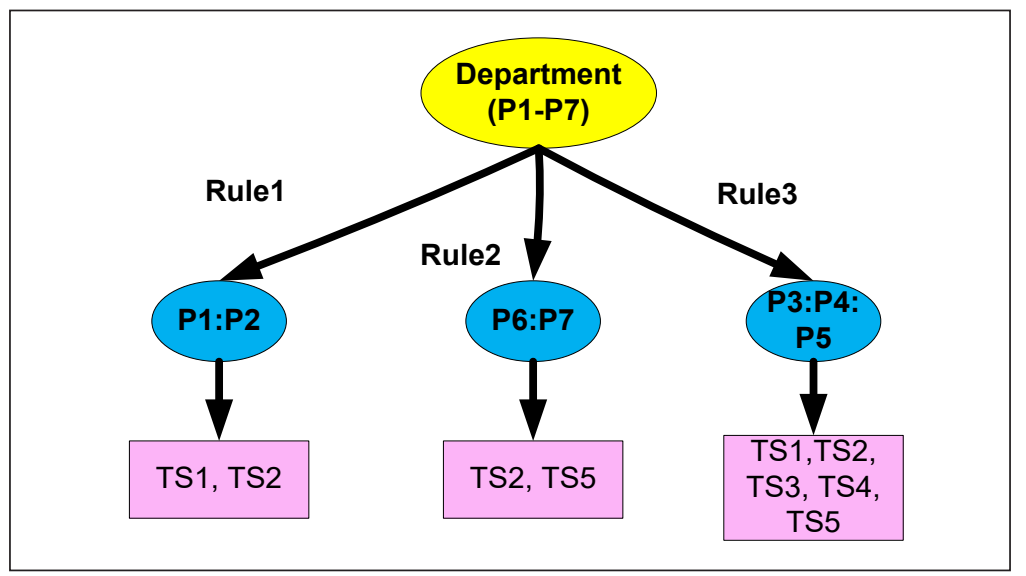

Figure 2. Decision tree diagram for FEP rule-based

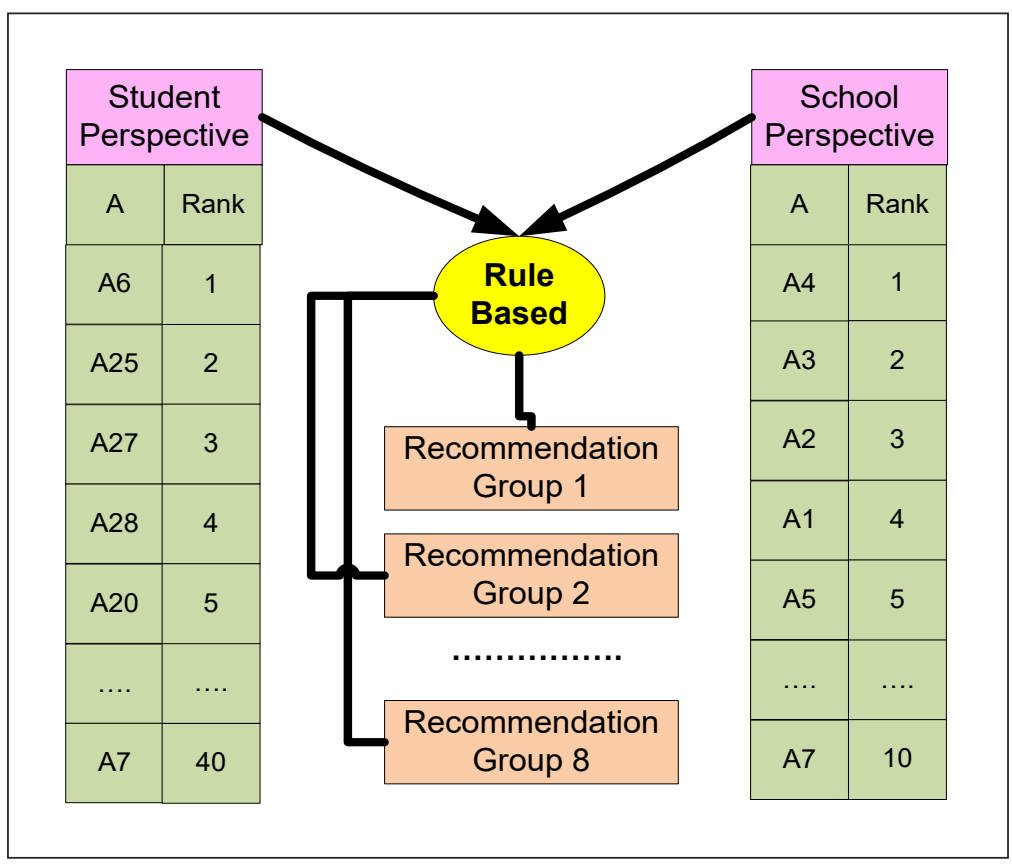

Figure 3. Integration of MOORA and Rule-based

formula as above (Rule 1 to 3). As a result, eight groups recommendation as in Table 9 is then suggested in Figure 3. Figure 3 elucidated that group one's recommendation is revealed from the first five rank students (A6, A25, A27, A28, A20) to be placed in the first three order schools (A4, A3, A2). The recommendation group two puts the sixth position students (A22, A24, A26, A5, A2) into school-A3, school-A2, school-A1, and reciprocally. For the detailed integration of MOORA and rule-based in eight groups, the detailed recommendation is interpreted in Table 9. 
Table 9

FEP student placement recommendation

\begin{tabular}{|c|c|c|c|c|c|}
\hline \multicolumn{6}{|c|}{ Recommendation Group 1} \\
\hline \multicolumn{2}{|c|}{ Alternatives (Student) by Rank } & \multirow{2}{*}{$\begin{array}{c}\text { Department } \\
\text { P3 }\end{array}$} & \multicolumn{2}{|c|}{ Alternatives (School) by Rank } & \multirow{2}{*}{$\begin{array}{c}\text { School Level } \\
\text { TS1 }\end{array}$} \\
\hline $\mathrm{A}_{6}$ & 1 & & $\mathrm{~A}_{4}$ & 1 & \\
\hline $\mathrm{A}_{25}$ & 2 & $\mathrm{P} 1$ & $\mathrm{~A}_{3}$ & 2 & TS1 \\
\hline $\mathrm{A}_{27}$ & 3 & $\mathrm{P} 1$ & $\mathrm{~A}_{2}$ & 3 & $\mathrm{TS} 2$ \\
\hline $\mathrm{A}_{28}$ & 4 & $\mathrm{P} 1$ & & & \\
\hline $\mathrm{A}_{20}$ & 5 & $\mathrm{P} 2$ & & & \\
\hline \multicolumn{6}{|c|}{ Recommendation Group 2} \\
\hline $\mathrm{A}_{22}$ & 6 & $\mathrm{P} 2$ & $\mathrm{~A}_{3}$ & 2 & TS1 \\
\hline $\mathrm{A}_{24}$ & 7 & $\mathrm{P} 2$ & $\mathrm{~A}_{2}$ & 3 & $\mathrm{TS} 2$ \\
\hline $\mathrm{A}_{26}$ & 8 & $\mathrm{P} 1$ & $\mathrm{~A}_{1}$ & 4 & $\mathrm{TS} 2$ \\
\hline $\mathrm{A}_{5}$ & 9 & P7 & & & \\
\hline $\mathrm{A}_{2}$ & 10 & P7 & & & \\
\hline \multicolumn{6}{|c|}{ Recommendation Group 3} \\
\hline $\mathrm{A}_{30}$ & 11 & P1 & $\mathrm{A}_{2}$ & 3 & TS2 \\
\hline $\mathrm{A}_{21}$ & 12 & $\mathrm{P} 2$ & $\mathrm{~A}_{1}$ & 4 & $\mathrm{TS} 2$ \\
\hline $\mathrm{A}_{32}$ & 13 & $\mathrm{P} 4$ & $\mathrm{~A}_{5}$ & 5 & TS3 \\
\hline $\mathrm{A}_{14}$ & 14 & P6 & & & \\
\hline $\mathrm{A}_{39}$ & 15 & P5 & & & \\
\hline$\ldots$ & $\ldots$ & $\ldots$ & $\ldots$ & $\ldots$ & $\ldots$ \\
\hline \multicolumn{6}{|c|}{ Recommendation Group 8} \\
\hline $\mathrm{A}_{11}$ & 36 & $\mathrm{P} 7$ & $\mathrm{~A}_{9}$ & 8 & TS5 \\
\hline $\mathrm{A}_{10}$ & 37 & P7 & $\mathrm{A}_{10}$ & 9 & TS5 \\
\hline $\mathrm{A}_{40}$ & 38 & P5 & $\mathrm{A}_{7}$ & 10 & TS4 \\
\hline $\mathrm{A}_{13}$ & 39 & P6 & & & \\
\hline $\mathrm{A}_{7}$ & 40 & P7 & & & \\
\hline
\end{tabular}

This study has generally established how the simple mathematical calculation in MOORA reveals the best decision-making by taking potential attributes into account (Arabsheybani et al., 2018) and prioritizing the alternative from several perspectives, namely students and schools' sides. This result is reinforced by Patnaik et al. (2020) findings that used the MOORA to juxtapose the material alternatives and correctly order them. Further, this study's evidence stated how a rule's functionality based on the IFTHEN feature's logical use provided the optimum recommendations from entangled rank alternatives of two sides perceives. In that sense, the rule base exhibited the ability in dealing with the complexity of possible cases and uncertainty in students placement intentions. Indeed, the algorithm of the decision tree, therefore, ensures the transparency of the student placement. 


\section{System Development}

A prototype of MOORA-Rulebased-DSS system as a management information system is designed and developed to automate the procedure of FEP, starting from the registration, management data of students and schools, management data of criteria and alternatives provided, management stakeholders internal and external as users, and integrated MOORA and Rule-based calculation procedures. The MOORA-Rulebased-DSS system architecture can be seen in Figure 4. Two key figures, namely the FEP committee and administrator, have engaged in this application to date. The administrator has access to the whole process of knowledge based. In the meantime, the committee received the recommendations suggested by the application.

\section{Testing}

To evaluate the MOORA-Rulebased-DSS, a UAT assessment's survey of twenty respondents came from five of the committees, eight study program leaders, two management schools, and five management faculty. The respondents are asked their perceives on the acceptance of MOORA-Rulebased-DSS application by considering the interactive design of system

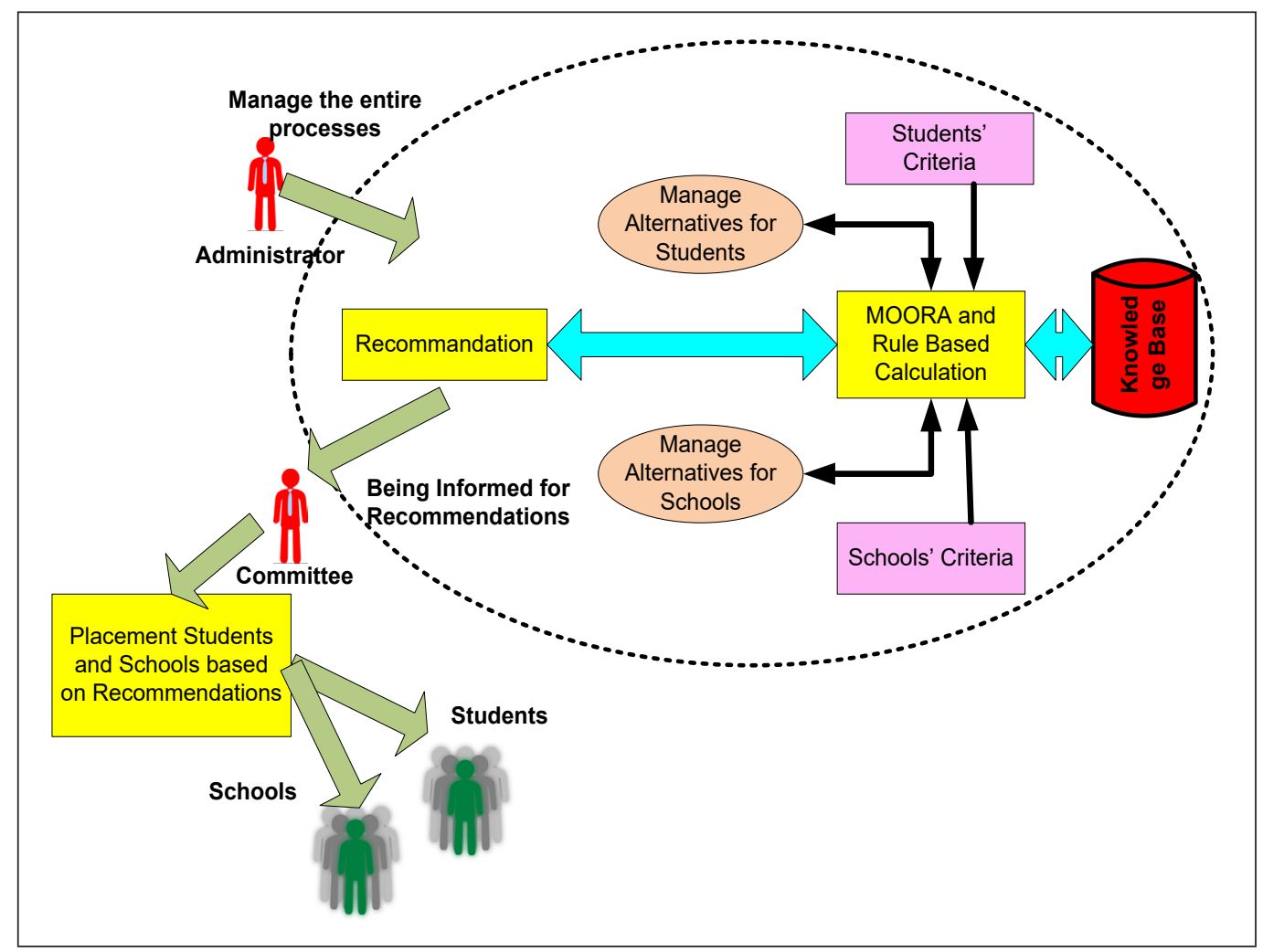

Figure 4. System architecture of MOORA-Rulebased-DSS 
interface (5 questions), the easy use of DSS system (5 questions), the system utilization in aiding management decision making (5 questions), and the agreement on the proposed DSS system recommendation (5 questions). As a result, it obtained a very agreeable response of $86.92 \%$ covenant. Subsequently, Blackbox testing is conveyed into several DSS system functions, including login, user updated data, students updated data alternatives, schools updated data alternative, MOORA execution, Rule-based execution, and MOORARulebased execution process. The testing revealed that $100 \%$ functionality and codifying test following the requirements analysis phase and user expectations. A Confusion Matrix is then generated by referring to Equation 5 and 6 . As a result, the Confusion Matrix achieved an accuracy value of $78.33 \%$ from 94 data tests with status "True" and $21.67 \%$ error rate from 26 data sets with conditional status "False". The calculation shows that this recommendation system succeeded in providing the most optimal advice in students' placement in the FEP.

\section{CONCLUSION}

This research has prevailed in propounding the optimal students' placement in the FEP. The multiple perspectives based on committee and schools have been accommodated by considering criteria and the adherence of MOORA calculation and rule based. The inclusion of rule-based has been successfully intensified the role of MOORA in optimizing the decisions. This recommendation system puts forward eight group suggestions as alternatives in placing the students for the FEP. The evaluation reveals the stakeholders' satisfaction and acceptance of the procedures and alternatives proposed. Hence, the emerging obstacles during the FEP can be minimized, and the stakeholders' amusement will be increased. Besides, the advancement of traineeship procedure and the suggested solution's objectivity impact the committee's performance towards the optimal, effective, and efficient services, especially in decision-making. Due to the constraints of user capabilities and knowledge from the committee, students, and schools' side on DSS system operation, the administration's role is playing significant values in managing the knowledge-based and data modelling. Therefore, future studies are encouraged to design the dynamic and smart DSS system. Therefore, all stakeholders will be directly involved and manage the knowledge based on the criteria and alternatives provided. Consequently, the efficiency of rule-based in complex environment tracking will linearly increase and powerful. Besides, the smart DSS system can accommodate more valuable perspectives.

\section{ACKNOWLEDGEMENT}

The authors fully acknowledged Faculty Science and Technology and Faculty Education and Teacher Training Universitas Islam Negeri Sultan Syarif Kasim Riau for data collection. It makes a high contribution to this research to be more viable and effective. 


\section{REFERENCES}

Akram, M., Ilyas, F., \& Garg, H. (2019). Multi-criteria group decision making based on ELECTRE-I method on Pythagorean fuzzy information. Soft Computing, 24(5), 3425-3453. https://doi.org/10.1007/s00500019-04105-0

Arabsheybani, A., Paydar, M. M., \& Safaei, A. S. (2018). An integrated fuzzy MOORA method and FMEA technique for sustainable supplier selection considering quantity discounts and supplier's risk. Journal of Cleaner Production, 190, 577-591. https://doi.org/10.1016/j.jclepro.2018.04.167

Ardana, I. M., Ariawan, I. P. W., \& Divayana, D. G. H. (2016). Development of decision support system to slection of the blended learning platforms for mathematics and ICT learning at SMK TI Udayana. International Journal of Advanced Research in Artificial Intelligence, 5(12), 15-18.

Bonjar, H. S., Salajegheh, S., Pourkiani, M., \& Sayadi, S. (2019). Identifying the dimensions and sustainable supply chain operations for knowledge-based decision making in Iran's tax affairs organization. International Journal of Supply Chain Management, 8(2), 735-743.

Brauers, W. K. M. (2008). Multi-objective contractor's ranking by applying the MOORA method. Journal of Business Economics and Management, 9(4), 245-255.

Brauers, W. K. M., \& Zavadskas, E. K. (2006). The Moora method and its application to privatization in a transition economy. Control and Cybernetics, Systems Research Institute of the Polish Academy of Sciences, 35(2), 445-469.

Büyüközkan, G., \& Güler, M. (2020). Smart watch evaluation with integrated hesitant fuzzy linguistic SAW-ARAS technique. Measurement, 153(March 2020), Article 107353. https://doi.org/10.1016/j. measurement.2019.107353

Carneiro, J., Alves, P., Marreiros, G., \& Novais, P. (2020). Group decision support systems for current times: Overcoming the challenges of dispersed group decision-making. Neurocomputing, 423, 735-746. https:// doi.org/10.1016/j.neucom.2020.04.100

Chakraborty, S. (2011). Applications of the MOORA method for decision making in manufacturing environment. International Journal of Advanced Manufacturing Technology, 54(9-12), 1155-1166. https:// doi.org/10.1007/s00170-010-2972-0

Chan, C. K., \& Yeung, N. C. J. (2019). Students' approach to develop in holistic competency: An adaption of the 3P model. An International Journal of Experimental Educational Psychology, 40(5), 1-21. https:// doi.org/10.1080/01443410.2019.1648767

Cherchye, L., De Witte, K., Ooghe, E., \& Nicaise, I. (2010). Efficiency and equity in private and public education: A nonparametric comparison. European Journal of Operational Research, 202, 563-573. https://doi.org/10.1016/j.ejor.2009.06.015

Conejero, J. M., Preciado, J. C., Prieto, A. E., Bas, M. C., \& Bolós, V. J. (2020). Applying data driven decision making to rank vocational and educational training programs with TOPSIS. Decision Support Systems, 142, 113470. https://doi.org/10.1016/j.dss.2020.113470

Copeland, L. (2004). A practitioner's guide to software test design. Artech House. 
Dabbagh, R., \& Yousefi, S. (2019). A hybrid decision-making approach based on FCM and MOORA for occupational health and safety risk analysis. Journal of Safety Research, 71, 111-123. https://doi. org/10.1016/j.jsr.2019.09.021

Davis, D. J., \& Ringsted, C. (2006). Accreditation of undergraduate and graduate medical education: How do the standards contribute to quality? Advances in Health Sciences Education, 11(3), 305-313. https://doi. org/10.1007/s10459-005-8555-4

Davis, F. D., \& Venkatesh, V. (2004). Toward pre prototype user acceptance testing of new information systems: Implications for software project management. IEEE Transactions on Engineering Management, 51(1), 31-46. https://doi.org/10.1109/TEM.2003.822468

De Farias Aires, R. F., \& Ferreira, L. (2019). A new approach to avoid rank reversal cases in the TOPSIS method. Computers \& Industrial Engineering, 132, 84-97. https://doi.org/10.1016/j.cie.2019.04.023

Delen, D., Topuz, K., \& Eryarsoy, E. (2020). Development of a Bayesian belief network-based DSS for predicting and understanding freshmen student attrition. European Journal of Operational Research, 281(3), 575-587. https://doi.org/10.1016/j.ejor.2019.03.037

Dinçer, H., Yüksel, S., \& Martínez, L. (2019). Interval type 2-based hybrid fuzzy evaluation of financial services in E7 economies with DEMATEL-ANP and MOORA methods. Applied Soft Computing, 79, 186-202. https://doi.org/10.1016/j.asoc.2019.03.018

Du, Y., Zheng, Y., Wu, G., \& Tang, Y. (2020). Decision-making method of heavy-duty machine tool remanufacturing based on AHP-entropy weight and extension theory. Journal of Cleaner Production, 252, Article 119607.

El-Gayar, O. F., \& Fritz, B. D. (2010). A web-based multi-perspective decision support system for information security planning. Decision Support Systems, 50(1), 43-54.

Emovon, I., Okpako, O. S., \& Edjokpa, E. (In Press). Application of fuzzy MOORA method in the design and fabrication of an automated hammering machine. World Journal of Engineering. https://doi.org/10.1108/ WJE-07-2020-0250

Engel, M. M., Utomo, W. H., \& Purnomo, H. D. (2017). Fuzzy multi attribute decision making - simple additive weighting (MADM - SAW) for information retrieval (IR) in e - commerce recommendation. International Journal of Computer Science and Software Engineering, 6(6), 136-145.

Fei, L., Xia, J., Feng, Y., \& Liu, L. (2019). An Electre-based multiple criteria decision-making method for supplier selection using Dempster-Shafer theory. IEEE Access, 7, 84701-84716. https://doi.org/10.1109/ ACCESS.2019.2924945

Fox, W. P., Ormond, B., \& Williams, A. (2015). Ranking terrorist targets using a hybrid AHP-TOPSIS methodology. Journal of Defense Modeling and Simulation: Applications, Methodology, Technology, 13(1), 77-93. https://doi.org/10.1177/1548512914563619

Gadakh, V. S., Shinde, V. B., \& Khemnar, N. S. (2013). Optimization of welding process parameters using MOORA method. International Journal of Advanced Manufacturing Technology, 69(9-12), 2031-2039. https://doi.org/10.1007/s00170-013-5188-2 
Gang, Z., Juanjo, M., \& Carmen, J. (2020). Chinese student teachers' teaching practicum experiences: Insights from transformative learning, third space, and dialogical-self theory. International Journal of Educational Research, 103, Article 101638.

Gràcia, M., Casanovas, J., Riba, C., Sancho, M. R., Jarque, M. J., Casanovas, J., \& Vega, F. (2020). Developing a digital application (EVALOE-DSS) for the professional development of teachers aiming to improve their students' linguistic competence. Computer Assisted Language Learning, 1-26. https://doi.org/10.1 080/09588221.2019.1707690

Gündoğdu, F. K., \& Kahraman, C. (2019). A novel fuzzy TOPSIS method using emerging interval-valued spherical fuzzy sets. Engineering Applications of Artificial Intelligence, 85, 307-23. https://doi. org/10.1016/j.engappai.2019.06.003

Han, J., Pei, J., \& Kamber, M. (2011). Data mining techniques (3rd Ed.). British Library.

Hemdi, M. A., Salehuddin, M. Z. M., \& Hafiz, M. H. (2016, December 1-2). Integrated cumulative grade point avarage (iCGPA): Concepts, challenges, and reality. In Proceedings of the Conference Heads of Academic Department (CHAD). ILD Nilai, UiTM, Malaysia.

Hsu, W. C. J., Liou, J. J. H., \& Lo, H. W. (2020). A group decision-making approach for exploring trends in the development of the healthcare industry in Taiwan. Decision Support Systems, 141, Article 113447. https://doi.org/10.1016/j.dss.2020.113447

Ibrahim, O., Sundgren, D., \& Larsson, A. (2014). An integrated decision support system framework for strategic planning in higher education institutions. In Proceedings of Joint International Conference on Group Decision and Negotiation: Group Decision and Negotiation. A Process-Oriented View (pp. 237-238). Springer. https://doi.org/10.1007/978-3-319-07179-4_27

Jones, A., Korson, S. J., Murray-Everett, N. C., Kessler, M. A., Harrison, D., Cronenberg, S., Parrish, M. L., \& Parsons, M. J. (2020). Teacher candidate tensions with the edTPA: A neoliberal policy analysis. In The Educational Forum (pp. 1-19). Routledge. https://doi.org/10.1080/00131725.2020.1790705

Julie, B., \& Katie, Z. (2017). A good news story: Early-career music teachers' accounts of their flourishing professional identities. Teaching and Teacher Education, 68, 241-251. https://doi.org/10.1016/j. tate.2017.08.009

Kacprzak, D. (2019). A doubly extended TOPSIS method for group decision making based on ordered fuzzy numbers. Expert System with Applications, 116, 243-254. https://doi.org/10.1016/j.eswa.2018.09.023

Kazemi, F., Bahrami, A., \& Sharif, J. A. (2020). Mineral processing plant site selection using integrated fuzzy cognitive map and fuzzy analytical hierarchy process approach: A case study of gilsonite mines in Iran. Minerals Engineering, 147, Article 106143. https://doi.org/10.1016/j.mineng.2019.106143

Kilic, H. S., Demirci, A. E., \& Delen, D. (2020). An integrated decision analysis methodology based on IFDEMATEL and IF-ELECTRE for personnel selection. Decision Support Syst, 137, Article 113360. https:// doi.org/10.1016/j.dss.2020.113360

Krisnawati, Y., Irawati, M., Rochman, F., \& Budiasih, E. (2015). The implementation of students' campaign program to form Adiwiyata school in Malang, Indonesia. International Journal of Research Studies in Education, 4(4), 53-65. 
Kumar, N., Singh, T., Grewal, J. S., Patnaik, A., \& Fekete, G. (2019). A novel hybrid AHP-SAW approach for optimal selection of natural fiber reinforced non-asbestos organic brake friction composites. Materials Research Express, 6(6), Article 065701.

Leny, N., \& Okfalisa. (2019). Measuring the sustainability performance of Islamic banking in Indonesia. Pertanika Journal Social Science \& Humanities, 27(2), 1073-1090.

Lewis, H. G., \& Brown, M. (2001). A generalized confusion matrix for assessing area estimates from remotely sensed data. International Journal of Remote Sensing, 22(16), 3223-3235. https://doi. org/10.1080/01431160152558332

Li, Z., Chow, D. H. C., Ding, D., Ying, J., Hu, Y., Chen, H., \& Zhao, W. (2020). The development and realization of a multi-faceted system for green building planning: A case in Ningbo using the fuzzy analytical hierarchy process. Energy \& Buildings, 226, Article 110371. https://doi.org/10.1016/j.enbuild.2020.110371

Liang, D., \& Xu Z. (2017). The new extension of TOPSIS method for multiple criteria decisions making with hesitant Pythagorean fuzzy sets. Applied Soft Computing, 60, 167-179. https://doi.org/10.1016/j. asoc.2017.06.034

Liang, Z. L., Yun, T. J., Oh, W. B., Lee, B. R., \& Kim, I. S. (2020). A study on MOORA-based Taguchi method for optimization in automated GMA welding process. Materials Today: Proceedings, 22, 1778-1785. https://doi.org/10.1016/j.matpr.2020.03.011

Liao, H. C., Wu, X., Mi, X., \& Herrera, F. (2020). An integrated method for cognitive complex multiple experts' multiple criteria decisions making based on ELECTRE III with weighted Borda rule. Omega, 93(C), Article 102052. https://doi.org/10.1016/j.omega.2019.03.010

Liu, D., \& Stewart, T. J. (2004). Object-oriented decision support system modelling for multicriteria decision making in natural resource management. Computers \& Operations Research, 31(7), 985-999. https://doi. org/10.1016/S0305-0548(03)00047-9

Madić, M., Radovanović, M., \& Petković, D. (2015). Non-conventional machining processes selection using multi-objective optimization on the basis of ratio analysis method. Journal of Engineering Science and Technology, 10(11), 1441-1452.

Mangla, S. K., Govindan, K., \& Luthra, S. (2017). Prioritizing the barriers to achieve sustainable consumption and production trends in supply chains using fuzzy Analytical Hierarchy Process. Journal of Cleaner Production, 151, 509-525. https://doi.org/10.1016/j.jclepro.2017.02.099

Martusorn, K. H., Chattrarat, K. B., \& Shaharudin, M. R. (2019). Comparative analysis of multiple criteria decision making (MCDM) approach in warehouse location selection of agricultural products in Thailand. International Journal of Supply Chain Management, 8(5), 168-175.

Memari, A., Dargi, A., Jokar, M. R. A., Ahmad, R., \& Rahim, A. R. A. (2019). Sustainable supplier selection: A multi-criteria intuitionistic fuzzy TOPSIS method. Journal of Manufacturing Systems, 50, 9-24. https:// doi.org/10.1016/j.jmsy.2018.11.002

Mishra, A. R., Singh, R. K., \& Motwani, D. (2020). Intuitionistic fuzzy divergence measure-based ELECTRE method for performance of cellular mobile telephone service providers. Neural Computing and Applications, 32, 3901-3921. https://doi.org/10.1007/s00521-018-3716-6 
Mistarihi, M. Z., Okour, R. A., \& Mumani, A. A. (2020). An integration of a QFD model with Fuzzy-ANP approach for determining the importance weights for engineering characteristics of the proposed wheelchair design. Applied Soft Computing Journal, 90, Article 106136. https://doi.org/10.1016/j.asoc.2020.106136

Mukodimah, S., Muslihudin, M., Andoyo, A., Hartati, S., \& Maseleno, A. (2018). Fuzzy simple additive weighting and its application to toddler healthy food. International Journal of Pure and Applied Mathematics, 118(7), 1-7.

Nidhra, S. (2012). Black box and white box testing techniques-A literature review. International Journal of Embedded Systems and Applications, 2(2), 29-50. https://doi.org/10.5121/ijesa.2012.2204

Okfalisa, O., Anugrah, S., Anggraini, W., Absor, M., Fauzi, S. S. M., \& Saktioto, S. (2018). Integrated analytical hierarchy process and objective matrix in balanced scorecard dashboard model for performance measurement. Telecommunication Computing Electronics and Control, 16(6), 2703-2711.

Okfalisa, O., Hidayati, R., Dwi, U. I., Pranggono, B., Elin, H., \& Saktioto, S. (2021). Decision support system for smartphone recommendation: The comparison of fuzzy AHP and fuzzy ANP in multi-attribute decision making. Journal SINERGI, 25(1), 101-110. https://doi.org/10.22441/sinergi.2021.1.013

Okfalisa, O., Zulfahri, Iswavigra, D. U., Megawati, \& Saktioto. (2020). Online shop recommendations: decision support system based on multi objective optimization on the basis of ratio analysis. In Proceeding in 8th International Conference on Cyber and IT Service Management (CITSM) (pp. 1-6). IEEE Conference Publication. https://doi.org/10.1109/CITSM50537.2020.9268848

Omrani, H., Alizadeh, A., \& Amini, M. (2019). A new approach based on BWM and MULTIMOORA methods for calculating semi-human development index: An application for provinces of Iran. Socio-Economic Planning Sciences, 70(C), Article 100689. https://doi.org/10.1016/j.seps.2019.02.004

Pardiyono, R., \& Indrayani, R. (2019). Decision support system to choose private higher education based on marketing mix model criteria in Indonesia. In IOP Conference Series: Materials Science and Engineering (Vol. 508, No. 1, p. 012112). IOP Publishing. https://doi.org/10.1088/1757-899X/508/1/012112

Patnaik, P. K., Swain, P. T. R., Mishra, S. K., Purohit, A., \& Biswas, S. (2020). Composite material selection for structural applications based on AHP-MOORA approach. Materials Today: Proceedings, 33(8), 56595663. https://doi.org/10.1016/j.matpr.2020.04.063

Petkov, D., Petkova, O., Andrew, T., \& Nepal, T. (2007). Mixing multiple criteria decisions making with soft systems thinking techniques for decision support in complex situations. Decision Support Systems, 43(4), 1615-1629. https://doi.org/10.1016/j.dss.2006.03.006

Pressman, R., \& Maxim, B. (2020). Software engineering: Practitioner's approach (9th Ed.). McGraw-Hill.

Roszkowska, E., \& Kacprzak, D. (2016). The fuzzy SAW and fuzzy TOPSIS procedures based on ordered fuzzy numbers. Information Science, 369, 564-584. https://doi.org/10.1016/j.ins.2016.07.044

Saban, A., \& Coklar, A. N. (2013). Pre-service teachers' opinions about the micro-teaching. The Turkish Online Journal of Educational Technology, 12(2), 234-240.

Selvi, K. (2010). Teachers' Competencies. International Journal of Philosophy of Culture and Axiology, 7(1), 167-176. https://doi.org/10.5840/cultura20107133 
Shihab, S. K., Khan, N. Z., Myla, P., Upadhyay, S., Khan, Z. A., \& Siddiquee, A. N. (2018). Application of MOORA method for multi optimization of GMAW process parameters in stain-less steel cladding. Management Science Letters, 8(4), 241-246. https://doi.org/10.5267/j.msl.2018.2.002

Stanujkic, D., Magdalinovic, N., Stojanovic, S., \& Jovanovic, R. (2012). Extension of ratio system part of MOORA method for solving decision-making problems with interval data. Informatica, 23(1), 141-154.

Sztubecka, M., Skiba, M., Mrówczyńska, M., \& Bazan-Krzywoszańska, A. (2020). An innovative decision support system to improve the energy efficiency of buildings in urban areas. Remote Sensing, 12(2), Article 259. https://doi.org/10.3390/rs12020259

Yazdani, M., Zarate, P., Coulibaly, A., \& Zavadskas, E. K. (2017). A group decision making support system in logistics and supply chain management. Expert Systems with Applications, 88, 376-392. https://doi. org/10.1016/j.eswa.2017.07.014

Yeo, L. S., Ang, R. P., Chong, W. H., Huan, V. S., \& Quek, C. L. (2008). Teacher efficacy in the context of teaching low achieving students. Current Psychology, 27(3), 192-204. https://doi.org/10.1007/s12144008-9034-x

You, Y., Sun, J., Jiang, J., \& Tan, Y. (2019). Belief-rule-base model with attribute reliability for multiple attribute decision making. In Proceedings of Chinese Control and Decision Conference (CCDC) (pp. 4770-4775). IEEE Conference Publication. https://doi.org/10.1109/CCDC.2019.8832405

Yusuf, T. I. (2019). A multi-objective credit evaluation model using MOORA method and goal programming. Arabian Journal of Science and Engineering, 45, 2035-2048. https://doi.org/10.1007/s13369-019-03930-7

Zendarski, N., Haebich, K., Bhide, S., Quek, J., Nicholson, J. M., Jacobs, K. E., Efrom, D., \& Sciberras, E. (2020). Student-teacher relationship quality in children with and without ADHD: A cross-sectional community-based study. Early Childhood Research Quarterly, 51, 275-284. https://doi.org/10.1016/j. ecresq.2019.12.006 